or $H$. luteipes, and has joints 5 to 10 of the antennæ more or less transverse. The male, according to Eppelsheim [Wien. ent. Zeit., xi, p. 294 (1892)], has the seventh ventral segment slightly produced, with the apex rounded.

Horsell, Woking :

November 5th, 1897.

\title{
NEUROPTERA OBSERVED IN 1897, CHIEFLY IN THE NEW FOREST
} AND IN THE FENS.

\section{BY KENNETH J. MORTON, F.E S.}

In July of the present year I had a long-looked-for opportunity of paying a visit to the New Forest, and the following notes are in greater part based on the resuits of collecting there. Possibly they do not add very much to our knowledge, and to those fortunate Neuropterists whose circumstances allow them to collect south of the Thames, they may have but a pallid interest; at the same time a few species are referred to which do not seem to fall in every one's way.

It would be superfluous to attempt any general description of collecting in the New Forest; plenty of records no doubt exist of first and other impressions. But I may say that I found it delightful and fully up to expectations. For a few days $I$ had the pleasure of my friend Mr. MeLachlan's companionship and guifance, and I cannot refrain from saying that I received much courtesy and help from others upon whom I had no claim.

On the way north 1 stayed in Cambridgeshire for a week or so, and thence made excursions into the neighbouring counties of Huntingdon and Northampton. The principal results there were in Lepidoptera, and I had the opportunity of seeing the flight of Apatura Iris for the first time. The capture of four of the British species of Thecla in and around the same wood witbin one week seems noteworthy; the species were Thecla betulce, quercûs, w-album and pruni. The last was of course much worn, and the first just appearing.

To a Neuropterist who has cullected in some of the well-watered parts of Scotland or Ireland, the comparative scarcity of caddis-flies in the New Forest does not excite wonder; on the other hand, the number of species of dragon-flies is surprising. But perhaps with so many conspicuous day-flying insects to distract attention, my collecting of the more retiring species may have been less thorough than it ought to have been. 
In any case, the dragon-flies stand in the front rank of my captures. The number of species taken in the various localities during the period of about three weeks, namely twenty-five, represents a very respectable proportion of the British list, and they are as follows:-

Sympetrum striolatum, Chp.-this was seen everywhere, and was especiaily common in Monkswood. S. sanguineum, Müller, was found both in Cambridgeshire and in Monkswood, but was not common; perhaps too early. S. scoticum, Don.New Forest and elsewhere.

Libellula quadrimaculata, L.-common in New Forest, it was as usual in numbers at Thorney in Cambridgeshire. L. fulva, Müller-near Ringwood I had the good fortune to secure a $\delta$ of this species, fully adult, and having the abdomen in a beautiful blue condition, which Mr. McLachlan informs me he had rarely hitherto seen in the British examples that have come under his notice.

Platetrum depressum, L. - stray specimens in beautifully adult coloration in the New Forest and Monkswood.

Orthetrum carulescens, F.- the most conspicuous dragon-fly in the New Forest.

Cordulia anea, L.-frequent at a pond near Ringwood, but getting frayed in the wings.

Cordulegaster annulatus, Latr.-common in New Forest, but not seen with certainty elsewhere.

Anax formosus, V. de Lind.-This fine insect, which I had never seen alive before, was evidently nearly over. Only one was seen in the New Forest, and another was taken near Herne, a veteran $\delta$ in perfect colours, but with frayed wings.

Eschna cyanea, Müller, and grandis, L.-neither species was taken, although I think both were seen in the south, but in Cambridgeshire, Huntingdonshire, and Northamptonshire, both were taken, and the latter was very common.

Brachytron pratense, Müller-a very fine $q$ taken in Monkswood, must surely have been a late straggler.

Calopteryx virgo, L.--common along all the New Forest streams.

Lestes nympha, Selys - the day after my arrival in Cambridgeshire was dull and damp, and I feared would prove useless for collecting dragon-flies. However, I made at once for the locality whence I had previously obtained a single of of $L$. nympha, and was particularly gratified to find, by sweeping the herbage in one ditch, that $L$. nympha was not only there but was in numbers, which were not subsequently exceeded when the sun was shining and the insects in flight. $L$. sponsa was also present with $L$. nympha, but for the first day or two they were evidently in much less mature condition than the latter species. The later appearance of $L$. sponsa is referred to by Dr. Ris in a recently published paper (Mitth. schw. ent. Gesell., 9, p. 433), and he also mentions that in Switzerland L. nympha is apparently intensely local. L. sponsa was of course very common nearly everywhere.

Platycnemis pennipes, Pallas-seen only near Brockenhurst, where it was common.

Ischnura elegans, V. de Lind., and Enallagma cyathigerum, Chp.-common. Agrion pulchellum, V. de Lind.-common at Thorney. A. puella, L.-common. 
A. mercuriale, Charp.-in company with Mr. McLachlan I took the species in some numbers in the locality pointed out by him, where he had found it the previous year, and a few days later it was observed rather more commonly near Emery Down. Mr. McLachlan's suggestion that it is probably not uncommon in the New Forest (Ent. Mo. Mag., vol. xx, 1st series, p. 255) will no doubt prove correct. Pyrrhosoma minium, Harris-common. P. tenellum, Villers-common at some of the New Forest bogs ; the form of the $q$ with black abdomen is not infrequent. Erythromma najas, Harris - a good many examples seen at an old brick hole near the Thorney river, flying over water lily leaves.

With regard to the several interesting dragon-flies which are apparently exclusively confined to the south-western counties, and which used to be taken by the old collectors, Ischnura pumilio, V. de Lind., is the one which has longest eluded the investigations of more recent workers, and seems still to await re-discovery. It is evidently much more fastidious about the conditions of the water it inhabits than I. elegans, which lives almost anywhere, and it is said by Dr. Ris to be found in Switzerland only at ponds and waters with a clay bottom, and to avoid peaty waters. Those searching for I. pumilio should also bear in mind that the flight of some dragon-flies is of very short duration. According to Ris, I. pumilio in Switzerland flies for a short time at the beginning of June, and soon vanishes to re-appear again in August.

Amongst the Trichoptera the most interesting species found in the New Forest was Phryganea minor, Curtis, which occurred abundantly about a dried-up pond in one of the enclosures by sweeping the herbage in the evening, and by disturbing them from the chinks of the bark of the surrounding trees during the day. Only one example was found away from this main locality; nearly all taken were females. $P$. varia, Fab., was also taken, and one of the larger species seen but not identified. Limnophilus luridus, Curt., is a very chapacteristic insect of the Forest. The other members of the genus Limnophilus taken were L.griseus, L. auricula, L.rhombicus, L. centralis, L. vittatus, and L. sparsus. Glyphotalius pellucidus, Oliv., was not uncommon. Isolated examples of Sericostoma personatum, Spence, occurred here and there, one $\delta$ being very curious in having hoary patches on the fore-wings; no difference from the normal form seems to exist in the genitalia as far as I have been able to examine these. Goëra pilosa, F., was represented by a few rather small examples. Leptocerus bilineatus, L., was the only noteworthy species of its family found in the Forest. Holocentropus dubius, Ramb., occurred at a pond near Ringwood. These are the more important caddis-flies noticed. The Hampshire Avon must be a fine stream for Trichoptera, but when it was visited the early summer species appeared to have already passed off.

In the other Neuropterous groups there is little to record. Only a single Raphidia (R. notata, Fab.) was seen. Hemerobius concinnus, Steph., was disturbed occasionally from fir trees when these were being knocked for Phryganea minor. Chrysopida abounded, but they appear to belong to the ordinary species. Panorpa 
communis and P.germanica both occurred, the former being the more common. Of Perlida, Nemoura variegata, Oliv., was the only common species, and the only other that was noticed at all was Isopteryx tripunctata, Scop.

Perhaps, on the whole, the time chosen for my excursion was rather late. The results, however, cannot be regarded as unsatisfactory.

13, Blackford Road, Edinburgh :

October, 1897.

Rhizophagus punctulatus, Guillebeau: synonymical note. - In the Bulletin de la Société Entomologique de France, 1897, p. 226, in a posthumous paper by F. Guillebeau, a new Rhizophagus is described under the name of R. punctulatus, upon three specimens from Nantua, Eastern France. This insect, from the description, is evidently conspecific with R. oblongicollis, Blatch and Horner [Ent. Mo. Mag., xxviii, p. 303 (1892)], from Sherwood Forest and Bagots Park. R. punctulatus is stated by Guillebeau to differ from $R$. ferrugineus and $R$. parallelocollis by the fine punctuation of the thorax and the shortness of the second joint of the antennæ, and from $R$. nitidulus by its ferruginous colour and the absence of the fovea upon the last ventral segment. I possess an example of $R$. oblongicollis, obtained from the Rev. T. Blackburn's British collection, without locality attached.-G. C. CHAMrion, Horsell, Woking : November $8 t h, 1897$.

Bagous nodulosus, Gyll., at Pevensey.-On May 3rd, when collecting near Pevensey with Mr. Donisthorpe, we were fortunate enough to meet with two or three specimens of Bagous nodulosus. It was apparently difficult to get, as several subsequent visits only produced a few examples, but a little later in the year I was fortunate enough to obtain a nice series. They are extremely sluggish, and, notwithstanding their large size, are more difficult to detect than any of the other species of the genus, as far as my experience goes; I found the best way to get them was with the water net. After dragging the aquatic vegetation very violently and repeatedly I took the whole of the mass in the net home, and found that repeated examinations were necessary before all the specimens were detected. To give some idea of how long they will remain without moving, I might mention that one specimen, when placed on a sheet of white paper, was fully ten minutes before it gave a sign of life. Other species that occurred in the same ditch were-Bagous alismatis and B.glabrirostris (common), Thryogenes scirrhosus (in numbers), Hypera Pollux, Cnemidotus impressus, Agabus Sturmi, Copelatus agilis, Hydroporus angustatus, Hydrobius oblongus, and Hydrophilus piceus.-W. ㅍ. B. Bennett, 15, Wellington Place, Hastings : October 25th, 1897.

A note on three British Histerida.-There are three genera in the Histerida, recognised by those who more particularly study the Family, which are not yet generally acknowledged by entomologists in England. Saprinus maritimus, Steph., is a typical Pachylopus (Erichson, 1834), a genus belonging to both the Old and New Worlds, but unlike Saprinus in being restricted in its number of species. About ten or twelve only are known, against about 400 of Saprinus. Kissister 


\section{$2 \mathrm{BHL}$ Biodiversity Heritage Library}

Morton, Kenneth J. 1897. "Neuroptera observed in 1897, chiefly in the new forest and in the fens." The Entomologist's monthly magazine 33, 275-278. https://doi.org/10.5962/bhl.part.18317.

View This Item Online: https://www.biodiversitylibrary.org/item/36026

DOI: https://doi.org/10.5962/bhl.part.18317

Permalink: https://www.biodiversitylibrary.org/partpdf/18317

\section{Holding Institution}

Smithsonian Libraries

\section{Sponsored by}

Smithsonian

\section{Copyright \& Reuse}

Copyright Status: NOT_IN_COPYRIGHT

This document was created from content at the Biodiversity Heritage Library, the world's largest open access digital library for biodiversity literature and archives. Visit BHL at https://www.biodiversitylibrary.org. 